\title{
Statistical Distribution of Halotolerant/Halophilic Biosurfactant- Producing Yeasts in Qua Iboe Estuarine Sediments
}

\section{Atim Asitok $^{1}$, Maurice Ekpenyong ${ }^{1}$}

\author{
${ }^{1}$ Environmental Microbiology and Biotechnology Unit, Department of Microbiology, Faculty of Biological \\ Sciences, University of Calabar, P.M.B. 1115, Calanar, Nigeria
}

\begin{abstract}
We isolated 100 morphologically-distinct halotolerant/halophilic yeasts from five estuarine sediments in Qua Iboe estuary, South-South Nigeria. A three-way analysis of variance (ANOVA) of the distribution was significant at $p<0.01$; adjusted $r^{2}=0.851$ suggesting that $85.1 \%$ of the variations in the number of halotolerant/halophilic yeast could be explained by the model. Sample, media and salt level main effects were all significant at $p<0.01, r^{2}=0.732 ; 0.403$ and 0.463 respectively. Only $17 \%$ of the yeasts demonstrated biosurfactant production potential by the oil displacement assay. Positive isolates were identified by macro/micro-morphological and physiological characterizations as species of Torulaspora, Pichia, Saccharomyces, Candida, Debaryomyces, Kluyveromyces, Schizosaccharomyces, Rhodotorula and Hortaea but the dominant halotolerant genus was Candida. Douglas creek sample harbored the highest number of halotolerant biosurfactant-producing yeasts probably by reason of its better proximity to Qua Iboe terminal where petroleum activity is high. Biosurfactants produced by all 17 yeasts could reduce surface tension to $<40 \mathrm{mN} / \mathrm{m}$ suggesting that halotolerant/halophilic yeasts in stressed environments secrete only effective surface-active compounds or not at all. Significant but moderate correlations existed between all correlate pairs involving oil displacement activity, surface tension, critical micelle concentration and emulsification activity of biosurfactants. The Pillai's Trace test of a one-way multivariate analysis of variance (MANOVA) involving surface tension reduction, oil displacement activity and emulsification activity was significant at $F(48,102)=3119.004, p<0.005$, partial $\eta^{2}=0.999$.
\end{abstract}

Keywords: Halotolerance/Halophily yeasts, Biosurfactant, Three-way ANOVA, Correlation analyses, One-way MANOVA

\section{Introduction}

In spite of the huge and direct impact of pathogenic and spoilage organisms on mankind and their materials, interest in industrial organisms continues on a heightened scale owing to their huge economic, health, agricultural, environmental and academic concerns. It is very difficult in today's world to pinpoint an aspect of global life that is not affected by the invisible life forms. By industrial microorganism is meant all microorganisms that could be exploited by man for the purpose of production of value-added metabolites or the provision of valuable services through the concenpt of biotechnology.

Industrial microbiology or microbial biotechnology, as it is fashionably called in recent times, has demonstrated the ability of industrial organisms to produce metabolites as varied as antibiotics [1], vitamins [2], amino acids [3], organic acids [4], hormones (steroids) [5], alcohols [6], single-cell proteins [7], vaccines [8] biopolymers [9], bioinsecticides [10], biocatalysts (enzymes) [11,12] and biosurfactants [13]. Documented evidence of applications of the afore-mentioned microbial metabolites exist in literature.

At the forefront of industrial microorganisms are bacteria, yeasts and molds. Most industrial bioprocesses reported in literature make use of bacteria but only a few bacteria have been able to pass off as 'generally recognized as safe (GRAS)' because of the pathogenic status of most bacteria [14] The propensity towards infection arising from consumption of these metabolites explains the huge amounts of money spent in purification steps to rid industrial bacterial metabolites of toxins, pyrogen and the like [15]. The yeasts have their fair share of that concern but not nearly as much perhaps owing to the inherent difficulty to indulge in indiscriminate horizontal gene transfer that characterizes bacteria, especially conjugation. Therefore, a very good

This article is published under the terms of the Creative Commons Attribution License 4.0

Author(s) retain the copyright of this article. Publication rights with Alkhaer Publications.

Published at: http://www.ijsciences.com/pub/issue/2019-06/

DOI: 10.18483/ijSci.2065; Online ISSN: 2305-3925; Print ISSN: 2410-4477 
number of yeast genera, species and strains, and the industrial metabolites derived therefrom, meet the GRAS status [16]. A lot of attention has therefore been focused on yeast metabolites as alternatives to bacterial metabolites to reduce cost of production and that of final product, reduce health and environmental risks that usually attend the use of pathogenic bacteria in microbial fermentation bioprocesses.

One of such yeast exploitations is in the production of the most versatile and multifuctional microbial biomolecule of the $20^{\text {th }}$ and $21^{\text {st }}$ century biosurfactants [17]. Biosurfactants are biological, essentially microbially-derived, amphiphilic compounds that lower the surface and interfacial tension of substances by means of their hydrophilic and hydrophobic domains. Their surface and interfacial tension reduction potentials confer on them properties as diverse as emulsification, wetting, detergency, foaming and solubilization of hydrophobic organic compounds [18]. These properties have variously been exploited in industries like food, pharmaceutical, cosmetic, petroleum and detergent industries [19]. Some of these industrial applications especially food processing and enhanced oil recovery operate at high salt $(\mathrm{NaCl})[20]$.

In this study, we investigated the distribution of halotolerant as well as halophilic yeast species in the estuarine sediments of the mangrove ecosystem of Qua Iboe River, Ibeno, Akwa Ibom State, Niger Delta region of Nigeria with potential for elaboration of surface-active compounds which would find applications in food processing and microbiallymediated enhanced recovery of oil (MEOR) in the petroleum industry.

\section{Methodology}

\subsection{Sample location and collection}

Qua Iboe estuary is a mesotidal ecotone in the Qua Iboe River located along coordinates Lat. $4^{\circ} 30^{\prime}-$ $4^{\circ} 45^{\prime} \mathrm{N}$ and Long. $7^{\circ} 31^{\prime}-8^{\circ} 45^{\prime} \mathrm{E}$ of Akwa Ibom State in the Niger Delta region of Nigeria. It experiences frequent intertidal fluctuations in salinity and is dominated by extensive intertidal mangrove and Nypa forested wetlands [21, 22]. The estuary is frigned with several creeks most of which have direct opening into the coastal marine system of the Atlantic ocean. Such creeks help conduct petroleum products that spill chronically from the Qua Iboe Terminal (QIT) where petroleum production and distribution activities of Exxon Mobile dominate [23]. Our study locations included five creeks namely Iwo-okpom, Mkpanak, Upenekang, Okposo and Douglas creeks. Sample collection sites and their distances were located by means of the Global Positioning System (GPS). The samples were collected into properly labeled $7 \mathrm{~cm}$ diameter bottles and transported in ice-packed coolers to the laboratory for microbiological analyses.

\subsection{Isolation od halotolerant/halophilic yeasts}

Halophily was defined as the ability of yeasts to grow in media containing $17 \%(\sim 3 \mathrm{M}) \mathrm{NaCl}$ [24] and halotolerance was defined as the ability of yeast species to grow in media containing $8.75 \%(\sim 1.5 \mathrm{M})$ $\mathrm{NaCl}$. Three media were employed for the isolations following 100-fold dilution of sediment samples, to prevent loss of desired species due to over-dilution. Screening media employed included malt-extract yeast-extract agar (MYA), glucose yeast-extract agar (GYA) and glucose yeast-extract-peptone agar (GYPA). Media were made selective for yeast by incorporation of $50 \mu \mathrm{g} / \mathrm{mL}$ of chloramphenicol and medium $\mathrm{pH}$ adjusted to 4.0 using $0.1 \mathrm{M} \mathrm{HCl} / \mathrm{NaOH}$ [25]. Each sample received treatment with all three media and quintuple replications of the arrangement were prepared for each treatment. A total of 150 plates were exposed to the isolation experiment; 75 for halophilic yeasts and 75 for halotolerant yeasts. All plates were incubated at $30^{\circ} \mathrm{C}$ for $30 \mathrm{~d}$. Cultural morphologies including pigmentation, elevation, margin, consistency and form were considered during isolation of morphologically-distinct halotolerant or halophilic yeast(s). Morphologically similar yeasts that occurred on more than one medium were only isolated from the medium where they made the most occurrence.

\subsection{Screening of halotolerant/halophilic yeast isolates for biosurfactant production}

2.3.1 Medium preparation for biosurfatant production by halotolerant/halophilic yeasts

Minimal medium containing (g/L) $\mathrm{KH}_{2} \mathrm{PO}_{4} \quad 1.0$; $\mathrm{K}_{2} \mathrm{HPO}_{4} \quad 0.5 ; \quad \mathrm{MgSO}_{4} .7 \mathrm{H}_{2} \mathrm{O} \quad 0.2 ; \quad \mathrm{NH}_{4} \mathrm{Cl} \quad 1.0 ;$ $\mathrm{FeSO}_{4} .7 \mathrm{H}_{2} \mathrm{O} 0.01$ [26] and supplemented with $1 \mathrm{~mL}$ of trace element solution containing $(\mathrm{g} / \mathrm{L})$ $\mathrm{ZnSO}_{4} .7 \mathrm{H}_{2} \mathrm{O} \quad 0.005 ; \quad \mathrm{MnSO}_{4} .4 \mathrm{H}_{2} \mathrm{O} \quad 0.005 ; \mathrm{H}_{3} \mathrm{BO}_{3}$ $0.005 ; \mathrm{CuSO}_{4} .5 \mathrm{H}_{2} \mathrm{O} \quad 0.005 ; \mathrm{CoCl}_{2} .6 \mathrm{H}_{2} \mathrm{O} \quad 0.005$; $\mathrm{MoNa}_{2} \mathrm{O}_{4} \cdot 2 \mathrm{H}_{2} \mathrm{O} 0.005$ and $\mathrm{NiCl}_{2} \cdot 6 \mathrm{H}_{2} \mathrm{O} 0.005$ [27] was used for potential biosurfactant elaboration. The medium was supplemented with $17 \% \mathrm{NaCl}$ (for halophilic yeasts) and $8.75 \% \mathrm{NaCl}$ for halotolerant yeasts. Glucose, olive oil or glycerol separately served as sole sources of carbon at $1 \%(\mathrm{v} / \mathrm{v}$ or $\mathrm{w} / \mathrm{v})$ and $\mathrm{pH}$ adjusted to 4.0 with $1 \mathrm{M} \mathrm{HCl} / \mathrm{IM} \mathrm{NaOH}$. Twenty milliliter volume of medium was dispensed into $100 \mathrm{~mL}$ Erlenmeyer flasks and sterilized by autoclaving at $121^{\circ} \mathrm{C}$ for $15 \mathrm{~min}$.

\subsubsection{Biosurfactant production and evaluation}

Upon cooling, flasks were inoculated with $2 \%(\mathrm{v} / \mathrm{v})$ 36 h-old broth culture of each yeast isolate. Broth cultures were prepared from the respective agar media on which the particular yeast was isolated 
minus agar-agar. Flasks were incubated at room temperature $\left(28 \pm 2^{\circ} \mathrm{C}\right)$ on a rotary shaker agitating at $150 \mathrm{rpm}$ for $21 \mathrm{~d}$.

Cell-free broth was obtained by centrifugation of flask content at $8,000 \mathrm{rpm}$ for $10 \mathrm{~min}$ and subjecting the supernatant to membrane filtration using, first, $0.45 \mu \mathrm{M}$ pore size filter (Millipore). The intact fermentation broth, sterile fermentation broth and yeast pellets all served as materials for biosurfactant screening.

The oil displacement assay of [28] was employed for biosurfactant screening. A linear relationship occurs between biosurfactant concentration and area of displaced oil [26] and the assay is sensitive enough to detect even nano-molar concentrations of the surfaceactive compound [28]. Briefly, $40 \mathrm{~mL}$ of distilled water was dispensed into a clean Petri dish of diameter $15 \mathrm{~cm}$. Thereafter, $15 \mu \mathrm{L}$ of Bonny medium crude oil was introduced at the center of the plate and allowed to equilibrate for $1 \mathrm{~h}$ producing a thin layer of oil film. The assay was performed by introducing $0.1 \mu \mathrm{L}$ of intact fermentation broth (IFB) or cell-free supernatant (CFB) or needle point sample of yeast pellet (YP) at the center of the oil film. Displacement of oil film from surface was scored as positive, otherwise negative. Diameters of displaced oil film were measured after $30 \mathrm{~s}$ by means of a meter rule and areas of displaced oil calculated using the equation $A=\pi r^{2}$, where $A$ is the area of biosurfactant-displaced oil film, $r$ the radius and $\pi$ a constant of value 3.14 . Triplicate measurements were made at all times.

\subsubsection{Assessment of biosurfactant properties}

2.3.3.1 Assessment of oil displacement activity

The oil displacement activity was assessed by the method of Morikawa et al. (1993) as described in section 2.3.2.

2.3.3.2 Measurement of surface tension reduction The surface tension reduction property was evaluated by the ring method of Du Nouy described in Rodrigues et al. [29] using CSC Du Nouy Tensiometer.

\subsubsection{Determination of the critical micelle concentration}

The efficiency of biosurfactant is given by its critical micelle concentration, defined as the minimum amount of biosurfactant required to form micelles and at which point further reduction in surface tension no longer occurs. This property was measured as described in Ekpenyong et al. [26]

\subsubsection{Measurement of the emulsification activity of biosurfactant}

The emulsification activities of all yeast biosurfactants were measured, using kerosene as hydrophobic compound. Equal volumes of cell-free biosurfactant broth and kerosene were mixed together in a test tube using vortex mixer (Vortex Mixer XHC, PEC MEDICAL, USA) for $10 \mathrm{~min}$. Thereafter, the mixture was allowed to stand for $24 \mathrm{~h}$. Emulsion (the white layer) height and total height of mixture were measured. The ratio of the height of emulsion to total height of mixture multiplied by 100 was determined and presented as \%E24.

\section{$2.4 \quad$ Identification of yeasts}

Positive yeasts were identified by cultural morphology, sexual structures involving number, shape and size of ascospores, asexual structures like hyphae and/or pseudohyphae. Physiological studies included sugar assimilation and cycloheximide resistance and nitrogen utilization [30].

\subsection{Statistical analyses}

Data generated were subjected to statistical analysis using descriptive statistics, pearson's correlation, two-way ANOVA and three-way ANOVA and oneway multivariate analysis of variance (MANOVA) using IBM-SPSS version 19. Bar graphs were plotted with Excel Software version 2007.

\section{$3 \quad$ Results and discussion}

3.1 Distribution of halotolerant/halophilic yeasts in sediment samples

The results of distribution of halotolerant and halophilic yeasts in Qua Iboe estuarine sediments are presented in Figure 1. A total of 100 morphologically-distinct types of yeasts were isolated from the five samples considered in the study. Fortyfive $(45 \%)$ of the yeasts were halotolerant while 55 $(55 \%)$ were able to grow in the presence of $17 \%$ $\mathrm{NaCl}$ as halophiles. Interestingly, all the isolates could grow optimally in the absence of salt suggesting that the definition of halophily in terms of amount of salt tolerated needs to be reviewed. Plemenitas et al. [31] reported that Hortaea werneckii is adapted to fluctuating concentrations of $\mathrm{NaCl}$ with growth optimum between 0.8 and $1.7 \mathrm{M}$. A truly halophilic yeast like Wallemia ichthiaphaga is reported to grow only in the presence of $\mathrm{NaCl}$ [32], however, we did not isolate it in this study.

When data was subjected to a three-way analysis of variance (ANOVA), the Levene's test of equality of error variances was not significant $(F: 1.165, p=.279$ $>0.05$ ) suggesting that the data did not violate the homogeneity of variance assumption and that we could proceed to interpret the results of the model. The results of test of between-subjects effect is 
presented as Table 1. The table reveals that the 3-way ANOVA model was significant at $p<0.01 ; r^{2}=$ 0.880 ; adjusted $r^{2}=0.851$, and could explain $85.1 \%$ of the variations in the number of halotolerant/halophilic yeast isolated from the five different samples. The result of sample main effect was significant; $p<0.01, r^{2}=0.732$ suggesting that $73.2 \%$ of the variations in the number of yeasts could be due to sample effect. Both media and salinity effects were respectively significant at $r^{2}=0.403$ and 0.463 . The contributions of the four interaction effects were similarly significant at $p<0.01$. The interaction between sample and media showed a coefficient of determination, $r^{2}$, given in the table as Partial Eta squared, of 0.517 indicating that the interaction was significant enough to explain $51.7 \%$ of the variables about the data. Sample/salt requirement interaction could explain $59.0 \%$ of variations about the data. Interestingly, the little contribution of media/salt requirement interaction of only $9.0 \%$ was significant enough at $p<0.01$ to mediate variations in the number of yeasts recovered from test samples. Finally, there was a significant three-way interaction among sample, media and salt requirement with an $r^{2}$ of 0.322 and capacity to influence $32.2 \%$ of the variations about the number of yeasts recovered from samples.

The interactive plots of the three-way interaction effects of the independent variables are presented in Figures $2 \mathrm{a}$ and $\mathrm{b}$. Because the error probabilities of the seven predictor terms were less than 0.05 and even 0.01 , we rejected all seven null hypotheses and accepted the alternative hypotheses as true; that significant differences existed in the mean number of yeasts recovered from the five different samples using three different media exposed to two different salt levels.

The Bonferroni post-hoc multiple comparison test results showed that mean differences in number of yeast between Utan Iyatah sample and all other four samples were significant. On the contrary, results also showed that the mean difference in number of yeast obtained from Douglas Creek did not differ significantly $(p=0.111>0.05)$ from that of Mkpanak
Creek sample. Non-significant mean differences also existed between Iwo-okpom and Mkpanak creek samples $(p=0.734>0.05)$, Iwo-okpom and Okposo samples $(p=1.000>0.05)$ as well as between Mkpanak and Okposo samples $(p=0.176>0.05)$. Mean differences between all media pairs were significant at $p<0.01 ; 0.05$ suggesting the strong influence of composition in mediating yeast colony development in isolation media.

\subsection{Screening of halotolerant/halophilic yeasts for biosurfactant production}

Results of screen test for biosurfactant production by halotolerant/halophilic yeasts showed that out of the 100 yeasts screened for biosurfactant production using three different substrates, 17 (17\%) could produce biosurfactant. Ten of the isolates were halotolerant yeasts while 7 were halophilic. Only DCHTM1 could produce biosurfactant in minimal medium when glucose served as carbon source and only UPHTM2 could produce biosurfactant when glycerol served as carbon source. All biosurfactantpositive isolates could produce biosurfactant in olive oil-minimal medium. This suggests that the major inducer substrates for biosurfactant production in those yeasts would be hydrophobic substrates.

In both DCHTM1 and UPHTM1, the bulk of surfaceactive compound was found associated with the yeast pellets. This suggests that the two yeast isolates will not be suitable for commercial production of the purified product by reason of the huge cost and tedion involved in product recovery. However, for enhanced oil recovery and hydrophobic compound remediation activities where purification is not an issue, isolate DCHTM1 would well pass with an oil displacement activity of $149.41 \mathrm{~cm}^{2}$ which, from Table 2, is higher than those produced by 13 of the isolates that were positive in olive oil-minimal medium. Biosurfactant production, measured as area of displaced oil, was found in the cell-free broth (CFB) of 9 isolates. Four isolates had their surfaceactive compounds as cell-associated but location of the active compound in 4 isolates was indeterminate as both cell-free broth (CFB) and yeast pellets (YP) could produce significant area of displaced oil. 


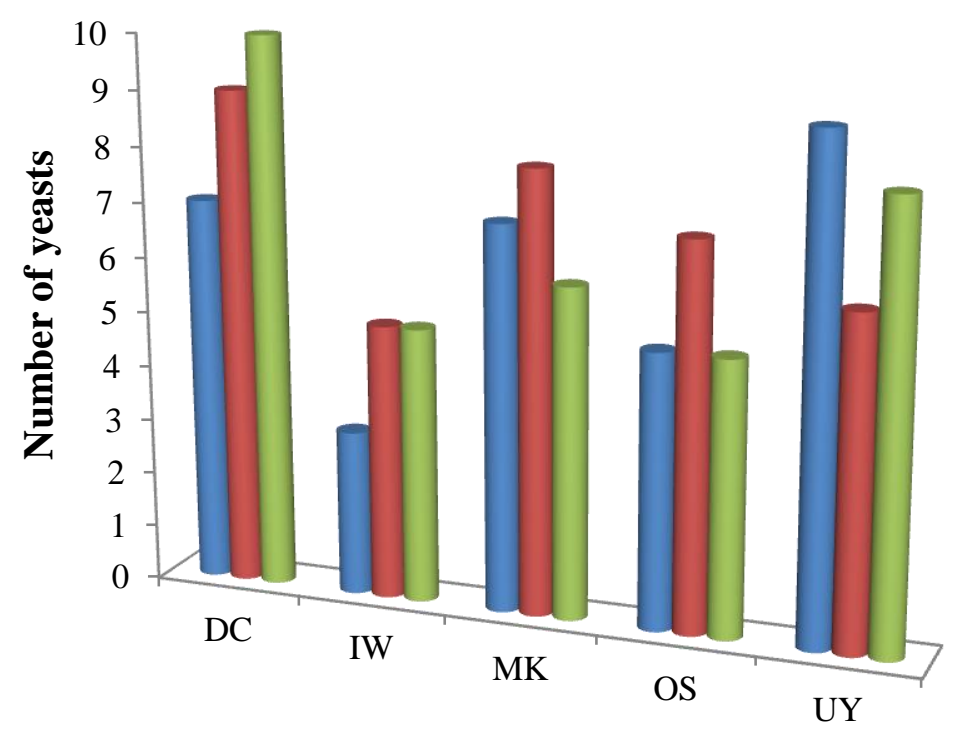

\section{Samples}

MYA $\square$ GYA $\square$ GYPA

Figure 1Number of halotolerant/halophilic yeast colonies as a function of samples/media

DC-Douglas Creek; IW-Iwo-okpom; MK-Mkpanak; OS-Okposo; UP-Upenekang; MYA-Malt-extract yeast-extract agar; GYA-Glucose yeast-extract agar; GYPA-Glucose yeast-extract peptone agar

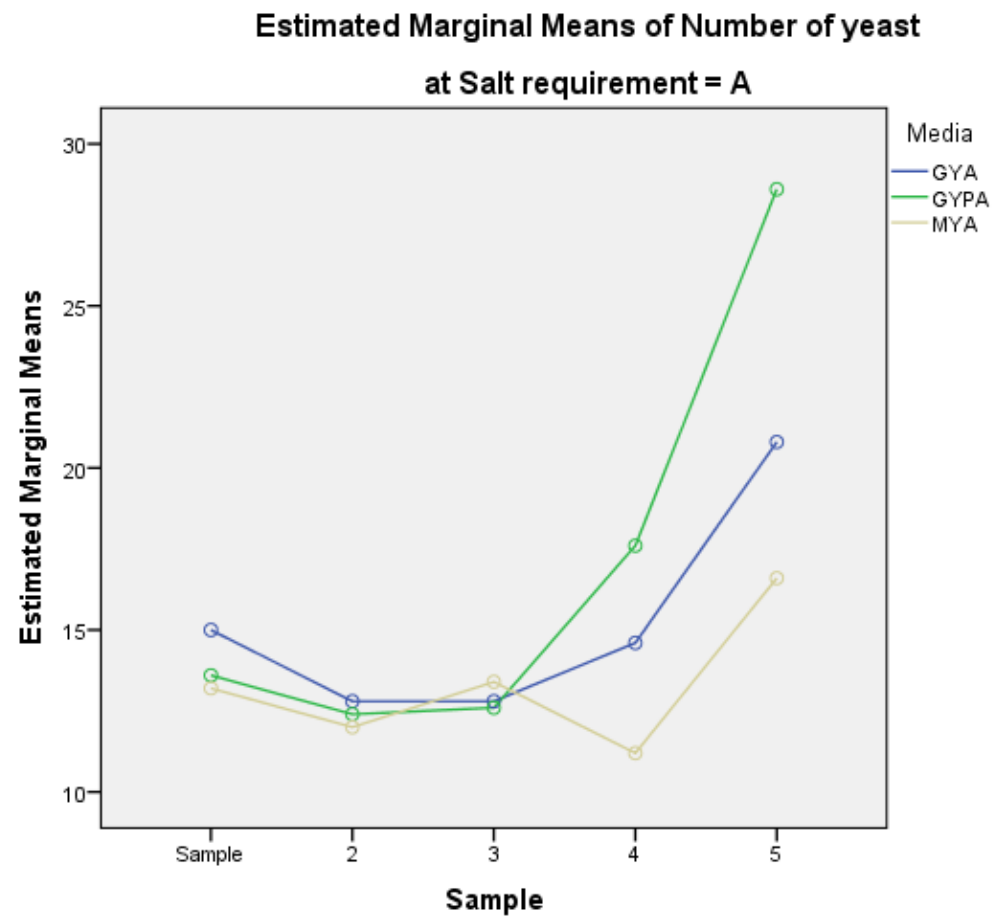

Figure 2a Three-way interactive effect plot of sample, media and $8.75 \% \mathrm{NaCl}$ on number of yeast 


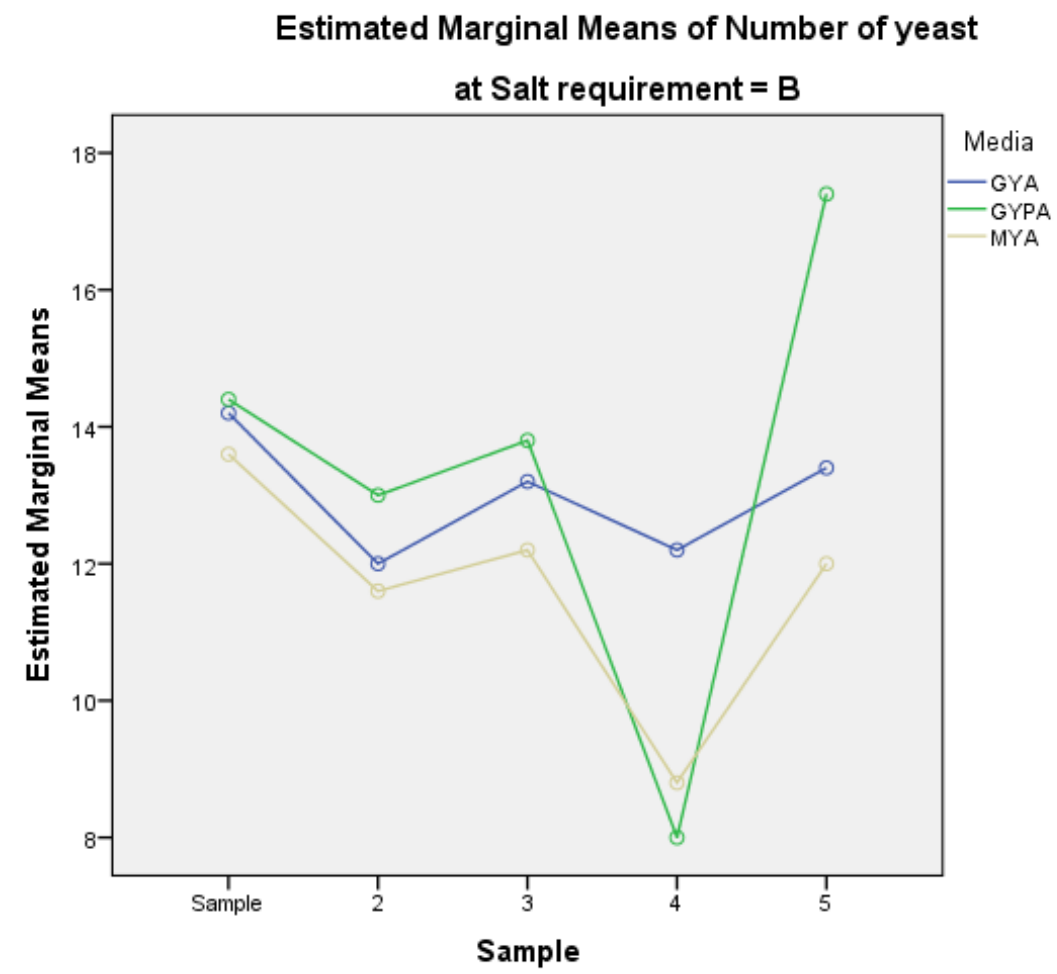

Figure $2 \mathbf{b}$ Three-way interactive effect plot of sample, media and $17 \% \mathrm{NaCl}$ on number of yeast

Table $1 \quad$ Test of between-subjects effects

\begin{tabular}{|c|c|c|c|c|c|c|}
\hline Source & $\begin{array}{c}\text { Type III Sum of } \\
\text { Squares }\end{array}$ & df & Mean Square & $F$ & Sig. & $\begin{array}{c}\text { Partial Eta } \\
\text { Squared }\end{array}$ \\
\hline Corrected Model & $1989.100^{\mathrm{a}}$ & 29 & 68.590 & 30.439 & .000 & .880 \\
\hline Intercept & 28981.500 & 1 & 28981.500 & 12861.612 & .000 & .991 \\
\hline Sample & 739.867 & 4 & 184.967 & 82.086 & .000 & .732 \\
\hline Media & 182.560 & 2 & 91.280 & 40.509 & .000 & .403 \\
\hline Salt level & 233.127 & 1 & 233.127 & 103.459 & .000 & .463 \\
\hline Sample * Media & 289.973 & 8 & 36.247 & 16.086 & .000 & .517 \\
\hline Sample $*$ Salt level & 388.773 & 4 & 97.193 & 43.133 & .000 & .590 \\
\hline Media * Salt level & 26.613 & 2 & 13.307 & 5.905 & .004 & .090 \\
\hline $\begin{array}{l}\text { Sample * Media * } \\
\text { Salt level }\end{array}$ & 128.187 & 8 & 16.023 & 7.111 & .000 & .322 \\
\hline Error & 270.400 & 120 & 2.253 & & & \\
\hline Total & 31241.000 & 150 & & & & \\
\hline Corrected Total & 2259.500 & 149 & & & & \\
\hline
\end{tabular}

a. $R$ Squared $=.880($ Adjusted $R$ Squared $=.851)$

A two-way ANOVA of data, however, revealed that location of biosurfactant was not significantly different among the yeasts but that nature of substrate significantly $(p=0.038<0.05)$ influenced biosurfactant production in the isolates. A similar observation was earlier made by Ekpenyong et al.
[26] in bacteria using five different substrates. The authors posited that the substrate chosen for biosurfactant production was a reflection of the use to which the organism would put the surface-active compound after synthesis. 


\subsection{Evaluation of biosurfactant properties}

Since all 17 yeast isolates could produce biosurfactant in olive oil-minimal medium and the time to demonstration of biosurfactant release in fermentation medium was shorter in that medium than in any other, all evaluations were conducted using olive oil-minimal medium. Results of oil displacement activities, surface tension reduction potentials, emulsification activities and critical micelle concentration of biosurfactants are also presented in Table 2. The table shows that the best five biosurfactant-producing yeasts in terms of oil displacement were UPHTM2 $\left(165.34 \mathrm{~cm}^{2}\right)$, OSHTG3 $\left(160.59 \mathrm{~cm}^{2}\right)$, UPHTP1 $\left(153.71 \mathrm{~cm}^{2}\right)$, DCHTM1 $\left(149.41 \mathrm{~cm}^{2}\right)$ and DCHPG2 $\left(145.69 \mathrm{~cm}^{2}\right)$. These isolates were obtained from Upenekang, Okposo and Douglas Creek samples. The codes of the isolates also indicate that the first four isolates were halotolerant yeasts while the last one was halophilic. The five poorest biosurfactant producers in terms of oil displacement activity were OSHPG1 $\left(55.61 \mathrm{~cm}^{2}\right)$, UPHTM1 (73.72 $\left.\mathrm{cm}^{2}\right)$, MKHPG1 $\left(75.61 \mathrm{~cm}^{2}\right)$, DCHTM2 $\left(91.63 \mathrm{~cm}^{2}\right)$ and OSHTP1 $\left(95.22 \mathrm{~cm}^{2}\right)$.

The effectiveness of a biosurfactant is measured by its surface tension reduction potential. The results presented in Table 2 show that surface-active compounds from all 17 isolates could reduce the surface-tension of minimal broth to $\leq 40 \mathrm{mN} / \mathrm{m}$. A biosurfactant is considered effective if it reduces surface tension of water from $72.00 \mathrm{mN} / \mathrm{m}$ to 40.00 $\mathrm{mN} / \mathrm{m}$ at room temperature [33]. Five yeasts isolates had biosurfactants with surface tension reduction potential below $30.00 \mathrm{mN} / \mathrm{m}$ and these included UPHTM2 $(28.48 \mathrm{mN} / \mathrm{m})$, OSHTG3 $(28.83 \mathrm{mN} / \mathrm{m})$, OSHPG1 $(29.57 \mathrm{mN} / \mathrm{m})$, MKHPP2 $(29.59 \mathrm{mN} / \mathrm{m})$ and UPHPM2 $(29.61 \mathrm{mN} / \mathrm{m})$. Apart from UPHTM2 and OSHTG3 isolates, the remaining three yeasts with very effective biosurfactants were different from the yeasts with excellent oil displacement activity. This suggests some form of relationship between oil displacement activity and surface tension reduction potential.
To establish the efficiency of a biosurfactant, we measured the critical micelle concentration $(\mathrm{cmc})$. The cmc answers the question: just how much biosurfactant is needed to bring about the surface tension reduction potential discussed in the earlier paragraph: the lower the $\mathrm{cmc}$, the more efficient the biosurfactant. The results presented in Table 2 reveal that UYHPM2 was the most efficient biosurfactant with a cmc of $18.71 \mathrm{mg} / \mathrm{L}$. Other efficient biosurfactants were from isolates OSHPG1 (19.38 mg/L), MKHPG1 (19.77 mg/L), DCHPG1 (21.54 $\mathrm{mg} / \mathrm{L})$ and DCHTM2 (22.67 mg/L). Once again, only isolate OSHPG1 has had an earlier mention in terms of excellence of activity.

Finally, results of emulsification activity of biosurfactants show that isolate DCHPG2 had the best emulsifying activity given by emulsification index of $77.71 \%$. Other biosurfactants with high emulsifying activities came from OSHTG3 (77.53\%), DCHTM1 (76.56\%), IWHTP1 (74.71\%) and OSHTG2 $(72.56 \%)$. Isolates OSHTG2 and IWHTP1 are now new entrants into the excellence activity group of biosurfactants. These results, as said earlier, only suggest some form of relationship among these activities.

Results of Pearson's bivariate correlations are presented in Table 3 and reveals that the four parameters of oil displacement activity (ODA), surface tension reduction potential (ST), critical micelle concentration $(\mathrm{cmc})$ and emulsifying activity (E24) very significantly $(p<0.01)$ correlated among one another. Oil displacement activity (ODA) had a positive but moderate correlation $(r=0.674)$ with E24 but its relationship with ST was negative, weak but significant $(r=-0.376, p=0.006<0.01)$ and that with cmc was positive but moderate $(r=0.539, p=$ $0.000<0.01)$. Surface tension $(\mathrm{ST})$ had moderately negative correlations of $r=-0.433, p=0.002<0.01$ and $r=-0.511, p=0.000<0.01$ with $\mathrm{cmc}$ and E24 respectively. Finally, $\mathrm{cmc}$ had a positive but weak correlation with E24 with a significant correlation coefficient of $r=0.370, p=0.008<0.01$. 
Statistical Distribution of Halotolerant/Halophilic Biosurfactant-Producing Yeasts in Qua Iboe Estuarine Sediments

\begin{tabular}{|c|c|c|c|c|c|}
\hline $\mathrm{S} / \mathrm{N}$ & Yeast isolate & $\begin{array}{l}\text { Area of displaced } \\
\text { oil of IFB }\left(\mathrm{cm}^{2}\right)\end{array}$ & $\begin{array}{l}\text { Surface tension } \\
(\text { dynes } / \mathrm{cm})\end{array}$ & $\begin{array}{l}\text { Critical micelle } \\
\text { concentration } \\
(\mathrm{mg} / \mathrm{L})\end{array}$ & $\begin{array}{l}\text { Emulsification } \\
\text { index (\% E24) }\end{array}$ \\
\hline 1 & DCHTM1 & $149.41 \pm 0.32$ & $32.73 \pm 0.03$ & $26.70 \pm 0.40$ & $76.56 \pm 0.29$ \\
\hline 2 & DCHTM2 & $91.63 \pm 0.19$ & $30.14 \pm 0.03$ & $22.67 \pm 0.15$ & $53.74 \pm 0.23$ \\
\hline 3 & DCHTM3 & $99.32 \pm 0.32$ & $37.39 \pm 0.13$ & $25.18 \pm 0.04$ & $57.31 \pm 0.11$ \\
\hline 4 & DCHPG1 & $122.48 \pm 0.51$ & $39.44 \pm 0.17$ & $21.54 \pm 0.21$ & $63.75 \pm 0.21$ \\
\hline 5 & DCHPG2 & $145.69 \pm 0.36$ & $30.44 \pm 0.21$ & $32.54 \pm 0.25$ & $77.71 \pm 0.23$ \\
\hline 6 & IWHTP1 & $105.27 \pm 0.40$ & $33.73 \pm 0.12$ & $28.57 \pm 0.42$ & $74.71 \pm 0.02$ \\
\hline 7 & MKHPM4 & $109.52 \pm 0.15$ & $39.91 \pm 0.25$ & $23.43 \pm 0.10$ & $45.40 \pm 0.13$ \\
\hline 8 & MKHPG1 & $75.61 \pm 0.17$ & $37.23 \pm 0.10$ & $19.77 \pm 0.17$ & $56.52 \pm 0.19$ \\
\hline 9 & MKHPP2 & $120.62 \pm 0.15$ & $29.59 \pm 0.16$ & $34.50 \pm 0.18$ & $68.58 \pm 0.19$ \\
\hline 10 & OSHTG2 & $100.43 \pm 0.12$ & $35.33 \pm 0.27$ & $25.61 \pm 0.06$ & $72.56 \pm 0.25$ \\
\hline 11 & OSHTG3 & $160.59 \pm 0.16$ & $28.83 \pm 0.14$ & $28.73 \pm 0.18$ & $77.53 \pm 0.27$ \\
\hline 12 & OSHTP1 & $95.22 \pm 0.16$ & $30.15 \pm 0.07$ & $23.47 \pm 0.18$ & $54.52 \pm 0.30$ \\
\hline 13 & OSHPG1 & $55.61 \pm 0.21$ & $29.57 \pm 0.21$ & $19.38 \pm 0.12$ & $58.23 \pm 0.14$ \\
\hline 14 & UpHTM1 & $73.72 \pm 0.17$ & $39.55 \pm 0.25$ & $23.72 \pm 0.11$ & $47.28 \pm 0.10$ \\
\hline 15 & UPHTM2 & $165.34 \pm 0.20$ & $28.48 \pm 0.17$ & $37.61 \pm 0.20$ & $72.51 \pm 0.15$ \\
\hline 16 & UPHTP1 & $153.71 \pm 0.24$ & $30.58 \pm 0.13$ & $23.64 \pm 0.19$ & $68.58 \pm 0.20$ \\
\hline 17 & UPHPM2 & $109.60 \pm 0.26$ & $29.61 \pm 0.12$ & $18.71 \pm 0.13$ & $67.56 \pm 0.20$ \\
\hline
\end{tabular}

HTM-Halotolerant yeast on malt-extract yeast-extract agar; HTG-Halotolerant yeast on glucose yeast-extract agar; HTP-Halotolerant yeast on glucose yeast-extract peptone agar; HPM-Halophilic yeast on malt-extract yeast-extract agar; HPG-Halophilic yeast on glucose yeast-extract agar; HPP-Halophilic yeast on glucose yeast extract peptone agar. DC-Douglas Creek; IW-Iwo-okpom; MK-Mkpanak; OS-Okposo; UP-Upenekang sampling locations

Since the bivariate correlations were moderate and so did not violate the multicolinearity assumption of multivariate analysis of variance (MANOVA) and the normality Q-Q plots seemed reasonably normal, we subjected the data for three of the continuous dependent variables (DVs) to MANOVA. The DVs were oil displacement activity, surface tension and emulsification activity. The independent variable (IV) was the yeast isolates (17 isolates). Because the Box $\mathrm{M}$ test for equality of covariance matrices was not computed, we interpreted the result of the most robust multivariate test, the Pillai's Trace. This multivariate test was significant at $F(48,102)=$ $3119.004, p<0.005$, partial $\eta^{2}=0.999$.

The Levene's test of equality of error variances tests the assumption of MANOVA that the variances of each variable are equal across groups. If the Levene's test is significant, then the assumption is violated and data would have to be transformed to equalize the variances. In this study, the Levene's test was not significant for any of the three dependent variables: Oil displacement activity, $F(2,18)=1.541, p=$ $0.142>0.05$; Surface tension, $F(2,18)=1.431, p=$ $0.185>0.05$; Emulsification index, $F(2,18)=1.143$, $p=0.359>0.05$. This suggests that the null hypothesis that the error variance of the dependent variables was equal across groups was true and so accepted.

The significant MANOVA multivariate test result permitted the interpretation of the univariate tests of between-subjects effects which are akin to three separate ANOVAs. Once again, all three dependent variables were statistically significant and so a posthoc test was conducted using Bonferroni multiple comparison. This is because the $p$-values for the ANOVAs on MANOVA do not take into account that multiple ANOVAs have been conducted. Therefore to protect against Type 1 error, Bonferroni post-hoc multiple comparisons, which adjust the alpha level to the number of dependent variables (0.05 divided by 3 ) is apt for pairwise contrast to locate where significant means are. In this study, all three ANOVAs were significant at the 0.017 adjusted alpha level as $p=0.000<0.017$.

The Bonferroni post-hoc multiple comparison tests revealed that mean differences between almost all biosurfactant activity pairs were significant $(p<$ 
0.05). Non-significant mean differences in oil displacement activity only existed between UPHPM2 and MKHPM4. The most non-significant $(p>0.05)$ pairwise mean differences occurred for surface tension and existed between DCHPG1 and MKHPM4, DCHPG1 and UPHTM1, DCHPG2 and DCHTM2, DCHPG2 and OSHTP1, DCHPG2 and UPHTP1, DCHTM2 and UPHPM2, DCHTM2 and UPHTP1, DCHTM3 and MKHPG1, and UPHTP1 and OSHTP1. Non-significant mean differences for emulsification activity occurred between DCHPG2 and UPHPM2, MKHPP2 and UPHTP1, OSHTG2 and UPHTM2.

\subsection{Yeast identities}

The identities of the 17 halotolerant/halophilic biosurfactant-producing yeasts isolated in this study are presented in Table 5. The identity of the isolates revealed a diverse genera of halotolerant yeasts in Qua Iboe Estuary. At least a single biosurfactant- producing halotolerant yeast was identified from each of the locations studied.

Candida: This genus had the highest number of biosurfactant-producing halotolerant yeasts isolated from study samples. Candida versatilis strain DCHPG1 and Candida tolerans strain DCHPG2 were halophilic yeasts isolated from Douglas creek sample while Candida tropicalis strain OSHTP1 and Candida magnoliae strain OSHPG1were respectively halotolerant and halophilic yeasts isolated from Okposo creek sample. None of the Candida strains could grow in the presence of diazonium blue-B but whereas $C$. versatilis and $C$. tropicalis could grow in the presence of $0.01 \%$ of cycloheximide, $C$. tolerans and $C$. magnoliae could not. Candida tolerans and $C$. tropicalis could grow over a wide range of temperature $\left(25-40^{\circ} \mathrm{C}\right)$ but those for the other species were narrow.

Table 3 Pearson's bivariate correlation of yeast biosurfactant activities

Correlations

\begin{tabular}{cccccc}
\hline & & ODA & ST & CMC & E24 \\
\hline ODA & Pearson Correlation & 1 & & & \\
& Sig. (2-tailed) & & & & \\
ST & Pearson Correlation & $-.376^{* * *}$ & 1 & & \\
& Sig. (2-tailed) & .006 & & & \\
CMC & Pearson Correlation & $.539^{* *}$ & $-.433^{* * *}$ & 1 & 1 \\
& Sig. (2-tailed) & .000 & .002 & & \\
E24 & Pearson Correlation & $.674^{* *}$ & $-.511^{* * *}$ & $.370^{* *}$ & \\
& Sig. (2-tailed) & .000 & .000 & .008 &
\end{tabular}

**. Correlation is significant at the 0.01 level (2-tailed). ODA-Oil displacement activity $\left(\mathrm{cm}^{2}\right)$; ST-Surface tension (dynes/cm); CMC-Critical micelle concentration (mg/L); E24-Emulsification activity (\%).

Table 4 Summary table for one-way multivariate analysis of variance (one-way MANOVA)

Multivariate Tests $^{\mathrm{a}}$

\begin{tabular}{cccccccc}
\hline & & & & & & \multicolumn{2}{c}{ Partial Eta } \\
& Effect & Value & $F$ & Hypothesis df & Error df & Sig. & Squared \\
\hline Intercept & Pillai's Trace & 1.000 & $6252854.978^{\mathrm{b}}$ & 3.000 & 32.000 & .000 & 1.000 \\
& Wilks' Lambda & .000 & $6252854.978^{\mathrm{b}}$ & 3.000 & 32.000 & .000 & 1.000 \\
& Hotelling's Trace & 586205.154 & $6252854.978^{\mathrm{b}}$ & 3.000 & 32.000 & .000 & 1.000 \\
& Roy's Largest & 586205.154 & $6252854.978^{\mathrm{b}}$ & 3.000 & 32.000 & .000 & 1.000 \\
& Root & & & & & & \\
\hline Yeast & Pillai's Trace & 2.998 & 3119.004 & 48.000 & 102.000 & .000 & .999 \\
code & Wilks' Lambda & .000 & 6532.717 & 48.000 & 95.970 & .000 & 1.000 \\
& Hotelling's Trace & 25456.570 & 16263.919 & 48.000 & 92.000 & .000 & 1.000 \\
& Roy's Largest & 22994.340 & $48862.973^{\mathrm{c}}$ & 16.000 & 34.000 & .000 & 1.000 \\
& Root & & & & & & \\
\hline
\end{tabular}

a. Design: Intercept + Yeast code

b. Exact statistic

c. The statistic is an upper bound on $F$ that yields a lower bound on the significance level. 
All strains of Candida in this study could use lysine as nitrogen source but only Candida versatilis and Candida magnoliae could assimilate nitrogen from the environmentally-abundant form of nitrogen, viz nitrate. The details of their carbon assimilation profiles are presented in Table 5. Their biosurfcatant production potentials also varied. Table 2 reveals that although the amount of biosurfactant produced by Candida mangoliae strain OSHPG1 was the least $\left(55.61 \mathrm{~cm}^{2}\right)$ and therefore produced marginal emulsification activity of $58.23 \%$, the biosurfactant was the most effective and efficient. However, $C$. tolerans biosurfactant is recommended for large-scale production for use in tertiary oil recovery, pharmaceutical formulations as well as in environmental bioremediation where its properties are required.

Surprisingly there are no reports on biosurfactant production by any strain of Candida versatilis, Candida tolerans and Candida magnoliae, however, copious reports exist for biosurfactant production by Candida tropicalis. Rubio-Ribeaux et al. [34] reported on the production of biosurfactant by Candida tropicalis strain UCP 1613 on renewable substrates. The active compound was able to reduce surface tension to $28.8 \mathrm{mN} / \mathrm{m}$ as against the 30.15 $\mathrm{mN} / \mathrm{m}$ in the present study.

Pichia: Three species of this genus were identified in this study and included the halotolerant strains of Pichia anomala strain DCHTM2, Pichia membranifaciens strain OSHTG3 isolated from Douglas and Okposo creeks respectively, and the halophilic Pichia farinosa strain MKHPG1 from Mkpanak Creek. Significantly, P. farinosa grew at $45^{\circ} \mathrm{C}$ while P. anomala and $P$. membranifaciens had their temperature maximum at $37^{\circ} \mathrm{C}$ and $35^{\circ} \mathrm{C}$ respectively. Pichia membranifaciens displayed very fastidious requirement for assimilable nitrogen and could only assimilate nitrogen from D-glucosamine but $P$. anomala was the only one of the three that could assimilate nitrogen from nitrate. In terms of carbon assimilation, P. membranifaciens was also quite stringent, using only glucose, glycerol and ethanol as sole sources of carbon and energy out of the 19 carbon sources tested. While $P$. farinosa could assimilate carbon from L-sorbose and D-xylose, $P$. anomala could not but rapidly developed growth when sucrose served as carbon source suggesting that the yeast is a good producer of invertase which splits sucrose into the component monosaccharides for effective carbon assimilation from glucose. The three species also significantly differed in terms of colonial morphology as $P$. anomala was cream in colour, $P$. fabrinosa white and $P$. membranifaciens was yellow.

Only Pichia membranifaciens strain OSHTG3 is recommended for biosurfactant production given the excellent properties of its biosurfactant presented in Table 2: Mean oil displacement activity of $160.59 \pm$ $0.16 \mathrm{~cm}^{2}$, mean surface tension reduction potential of $28.83 \pm 0.14 \mathrm{mN} / \mathrm{m}$, mean critical micelle concentration of $28.73 \pm 0.18 \mathrm{mg} / \mathrm{L}$ and mean emulsification activity of $77.53 \pm 0.27 \%$. However, Thaniyavarn et al. [35] produced sophorolipid from Pichia anomala strain PY1 when grown on soybean oil as carbon source. Surface tension decreased to 28 $\mathrm{mN} / \mathrm{m}$ with an oil displacement activity of $69.43 \mathrm{~cm}^{2}$. Our Pichia anomala strain could reduce surface tension to $30 \mathrm{mN} / \mathrm{m}$ with an oil displacement activity of $91.63 \mathrm{~cm}^{2}$ at a $\mathrm{cmc}$ of $22.67 \mathrm{mg} / \mathrm{L}$. The major sources of difference between the two reports could be attributaed to carbon source and $\mathrm{NaCl}$ stress.

Torulaspora: Two species of this genus were isolated from Douglas and Mkpanak creeks. The species from Douglas Creek was identified as Torulaspora globosa strain DCHTM1 while that from Mkpanak creek was Torulaspora delbrueckii strain MKHPP2. From the strain code of the yeast, T. globosa was halotolerant, growing in the presence of $\mathrm{NaCl}$ concentration of $8.75 \%(\mathrm{w} / \mathrm{v})$ and $T$. delbrueckii was halophilic capable of growth in $17 \%(w / v) ~ \mathrm{NaCl}$ within $21 \mathrm{~d}$. Very significant differences between the two strains were that $T$. globosa could grow in the presence of $0.01 \%$ cycloheximide while $T$. belbrueckii could not. While $T$. delbrueckii could grow at $25^{\circ} \mathrm{C}, T$. globosa could not. Interestingly, while $T$. globosa had a convex growth in agar media, T. delbrueckii appeared concave on glucose yeastextract peptone agar. Torulaspora globosa produced larger amount of biosurfactant than $T$. delbrueckii, however, the surface-active compound was less effective than that of the later. 
Statistical Distribution of Halotolerant/Halophilic Biosurfactant-Producing Yeasts in Qua Iboe Estuarine Sediments

\begin{tabular}{|c|c|c|c|c|c|c|c|c|c|c|c|c|c|c|c|c|c|}
\hline Tests & 1 & 2 & 3 & 4 & 5 & 6 & 7 & 8 & 9 & 10 & 11 & 12 & 13 & 14 & 15 & 16 & 17 \\
\hline \multicolumn{18}{|c|}{ Morphology } \\
\hline Colour & TW & $\mathrm{Crm}$ & $\mathrm{Crm}$ & Wte & $\mathrm{Crm}$ & Yell & Yell & Wte & $\mathrm{Crm}$ & Bwn & Yell & $\mathrm{Crm}$ & $\mathrm{Crm}$ & $\mathrm{Crm}$ & Red & Pink & Black \\
\hline Elevation & -vex & Rsd & Flat & Rsd & Rsd & -cave & Rsd & Rsd & -cave & -cave & Rsd & Rsd & Rsd & Rsd & Rsd & -cave & -cave \\
\hline Texture & Buty & Buty & Buty & Buty & Wet & Buty & Buty & Buty & Buty & Wet & Wet & Wet & Buty & Buty & Mucoid & Buty & Mucoid \\
\hline Shape & Sphe & Sphe & Oblong & Oval & Sphe & Oval & Oval & Oval & Oval & Oval & Sphe & Cylin & Oval & Oval & Cylin & Cylin & Cylin \\
\hline Size & Med & Small & Med & Small & Small & Med & Small & Med & Small & Med & Med & Small & Large & Med & Large & Med & Small \\
\hline Ascospore & Pr & Pr & $\operatorname{Pr}$ & A & A & $\operatorname{Pr}$ & $\operatorname{Pr}$ & $\operatorname{Pr}$ & A & Pr & Pr & A & A & $\operatorname{Pr}$ & A & A & A \\
\hline P-hyphae & Pr & $\operatorname{Pr}$ & Pr & A & $\operatorname{Pr}$ & A & Pr & Pr & A & A & Pr & Pr & A & A & Pr & A & A \\
\hline Hyphae & A & $\mathrm{A}$ & $\mathrm{A}$ & $\mathrm{A}$ & $\mathrm{A}$ & $\mathrm{A}$ & $\mathrm{A}$ & $\mathrm{A}$ & $\mathrm{A}$ & Pr & $\mathrm{A}$ & Pr & A & $\mathrm{A}$ & $\mathrm{A}$ & $\mathrm{A}$ & Pr \\
\hline \multicolumn{18}{|c|}{ Carbon Assimilation } \\
\hline D-Glucose & $\mathrm{P}$ & $P$ & $P$ & $P$ & $P$ & $P$ & $P$ & $P$ & $\mathrm{P}$ & $P$ & $P$ & $P$ & $P$ & $P$ & $P$ & $P$ & $P$ \\
\hline D-Gal & $\mathrm{N}$ & $P$ & $P$ & $P$ & $\mathrm{~N}$ & $P$ & $P$ & $P$ & $\mathrm{~N}$ & $P$ & $\mathrm{~N}$ & $P$ & $\mathrm{~N}$ & $\mathrm{~N}$ & $\mathrm{~N}$ & $\mathrm{~N}$ & $\mathrm{~N}$ \\
\hline L-Sorbose & $\mathrm{N}$ & $\mathrm{N}$ & $\mathrm{N}$ & $\mathrm{N}$ & $P$ & $P$ & $P$ & $P$ & $\mathrm{~N}$ & $\mathrm{~N}$ & $\mathrm{~N}$ & $\mathrm{~N}$ & $P$ & $\mathrm{~N}$ & $\mathrm{~N}$ & $P$ & $\mathrm{~N}$ \\
\hline D-Xylose & $\mathrm{N}$ & $\mathrm{N}$ & $\mathrm{N}$ & $\mathrm{N}$ & $P$ & $P$ & $P$ & $P$ & $P$ & $\mathrm{~N}$ & $\mathrm{~N}$ & $P$ & $\mathrm{~N}$ & $\mathrm{~N}$ & $P$ & $P$ & $\mathrm{~N}$ \\
\hline D-Ara & $\mathrm{N}$ & $\mathrm{N}$ & $\mathrm{N}$ & $\mathrm{N}$ & $\mathrm{N}$ & $\mathrm{N}$ & $\mathrm{P}$ & $\mathrm{N}$ & $\mathrm{P}$ & $\mathrm{N}$ & $\mathrm{N}$ & $\mathrm{N}$ & $\mathrm{N}$ & $\mathrm{N}$ & $P$ & $\mathrm{~N}$ & $\mathrm{~N}$ \\
\hline L-Rham & $\mathrm{N}$ & $\mathrm{N}$ & $\mathrm{N}$ & $\mathrm{N}$ & $\mathrm{N}$ & $P$ & $P$ & $\mathrm{~N}$ & $\mathrm{~N}$ & $\mathrm{~N}$ & $\mathrm{~N}$ & $\mathrm{~N}$ & $\mathrm{~N}$ & $\mathrm{~N}$ & $\mathrm{~N}$ & $\mathrm{~N}$ & $\mathrm{~N}$ \\
\hline Sucrose & $P$ & $P$ & $\mathrm{P}$ & $P$ & $P$ & $P$ & $P$ & $\mathrm{~N}$ & $\mathrm{~N}$ & $\mathrm{P}$ & $\mathrm{N}$ & $P$ & $\mathrm{~N}$ & $P$ & $P$ & $\mathrm{~N}$ & $\mathrm{~N}$ \\
\hline Maltose & $\mathrm{N}$ & $P$ & $\mathrm{~N}$ & $P$ & $\mathrm{P}$ & $P$ & $P$ & $\mathrm{~N}$ & $\mathrm{~N}$ & $\mathrm{~N}$ & $\mathrm{~N}$ & $P$ & $\mathrm{~N}$ & $P$ & $\mathrm{~N}$ & $\mathrm{~N}$ & $\mathrm{~N}$ \\
\hline Cellobiose & $\mathrm{N}$ & $P$ & $\mathrm{~N}$ & $P$ & $\mathrm{~N}$ & $P$ & $P$ & $\mathrm{~N}$ & $\mathrm{P}$ & $\mathrm{N}$ & $\mathrm{N}$ & $P$ & $\mathrm{~N}$ & $\mathrm{~N}$ & $\mathrm{~N}$ & $\mathrm{~N}$ & $\mathrm{~N}$ \\
\hline Lactose & $\mathrm{N}$ & $\mathrm{N}$ & $\mathrm{N}$ & $P$ & $\mathrm{~N}$ & $P$ & $P$ & $\mathrm{P}$ & $\mathrm{N}$ & $\mathrm{P}$ & $\mathrm{N}$ & $\mathrm{N}$ & $\mathrm{N}$ & $\mathrm{N}$ & $\mathrm{N}$ & $\mathrm{N}$ & $P$ \\
\hline Raffinose & $P$ & $P$ & $\mathrm{P}$ & $\mathrm{N}$ & $P$ & $P$ & $\mathrm{P}$ & $\mathrm{N}$ & $\mathrm{N}$ & $P$ & $\mathrm{~N}$ & $\mathrm{~N}$ & $\mathrm{~N}$ & $P$ & $\mathrm{P}$ & $P$ & $\mathrm{~N}$ \\
\hline D-Manni & $P$ & $\mathrm{P}$ & $\mathrm{N}$ & $P$ & $P$ & $P$ & $P$ & $\mathrm{P}$ & $\mathrm{N}$ & $P$ & $\mathrm{~N}$ & $P$ & $P$ & $\mathrm{~N}$ & $P$ & $\mathrm{~N}$ & $\mathrm{~N}$ \\
\hline Inulin & $P$ & $\mathrm{~N}$ & $\mathrm{~N}$ & $\mathrm{~N}$ & $\mathrm{~N}$ & $P$ & $\mathrm{~N}$ & $\mathrm{~N}$ & $\mathrm{~N}$ & $\mathrm{P}$ & $\mathrm{N}$ & $\mathrm{N}$ & $\mathrm{N}$ & $P$ & $\mathrm{~N}$ & $\mathrm{~N}$ & $\mathrm{~N}$ \\
\hline Starch & $\mathrm{N}$ & $\mathrm{N}$ & $\mathrm{N}$ & $\mathrm{N}$ & $P$ & $P$ & $P$ & $\mathrm{~N}$ & $\mathrm{~N}$ & $\mathrm{~N}$ & $\mathrm{~N}$ & $P$ & $\mathrm{~N}$ & $P$ & $\mathrm{~N}$ & $\mathrm{~N}$ & $\mathrm{~N}$ \\
\hline Glycerol & $P$ & $P$ & $\mathrm{~N}$ & $P$ & $P$ & $P$ & $P$ & $\mathrm{P}$ & $\mathrm{N}$ & $\mathrm{N}$ & $P$ & $\mathrm{~N}$ & $P$ & $\mathrm{~N}$ & $\mathrm{~N}$ & $P$ & $\mathrm{~N}$ \\
\hline Citrate & $\mathrm{N}$ & $P$ & $\mathrm{~N}$ & $P$ & $P$ & $P$ & $P$ & $P$ & $\mathrm{P}$ & $\mathrm{N}$ & $\mathrm{N}$ & $\mathrm{N}$ & $P$ & $\mathrm{~N}$ & $\mathrm{~N}$ & $\mathrm{~N}$ & $\mathrm{~N}$ \\
\hline D-Glucon & $P$ & $\mathrm{~N}$ & $\mathrm{~N}$ & $\mathrm{~N}$ & $\mathrm{~N}$ & $\mathrm{~N}$ & $P$ & $\mathrm{~N}$ & $\mathrm{~N}$ & $\mathrm{~N}$ & $\mathrm{~N}$ & $\mathrm{~N}$ & $P$ & $P$ & $\mathrm{~N}$ & $P$ & $\mathrm{~N}$ \\
\hline Methanol & $\mathrm{N}$ & $\mathrm{N}$ & $\mathrm{N}$ & $\mathrm{N}$ & $\mathrm{N}$ & $\mathrm{N}$ & $P$ & $\mathrm{~N}$ & $\mathrm{~N}$ & $\mathrm{~N}$ & $\mathrm{~N}$ & $\mathrm{~N}$ & $\mathrm{~N}$ & $\mathrm{~N}$ & $\mathrm{~N}$ & $\mathrm{~N}$ & $\mathrm{~N}$ \\
\hline Ethanol & $P$ & $P$ & $\mathrm{P}$ & $P$ & $P$ & $P$ & $\mathrm{P}$ & $P$ & $\mathrm{~N}$ & $\mathrm{P}$ & $P$ & $\mathrm{P}$ & $\mathrm{N}$ & $\mathrm{P}$ & $P$ & $P$ & $\mathrm{~N}$ \\
\hline
\end{tabular}

Table 5

Characterization and identification of yeast isolates cont.

\begin{tabular}{|c|c|c|c|c|c|c|c|c|c|c|c|c|c|c|c|c|c|}
\hline Tests & 1 & 2 & 3 & 4 & 5 & 6 & 7 & 8 & 9 & 10 & 11 & 12 & 13 & 14 & 15 & 16 & 17 \\
\hline \multicolumn{18}{|c|}{ Nitrogen assimilation } \\
\hline Nitrate & $\mathrm{N}$ & $P$ & $\mathrm{~N}$ & $P$ & $\mathrm{~N}$ & $\mathrm{~N}$ & $\mathrm{~N}$ & $\mathrm{~N}$ & $\mathrm{~N}$ & $\mathrm{~N}$ & $\mathrm{~N}$ & $\mathrm{~N}$ & $P$ & $\mathrm{~N}$ & $P$ & $\mathrm{~N}$ & $P$ \\
\hline Nitrite & $\mathrm{P}$ & $\mathrm{N}$ & $\mathrm{N}$ & $P$ & $\mathrm{~N}$ & $\mathrm{~N}$ & $\mathrm{~N}$ & $\mathrm{~N}$ & $\mathrm{~N}$ & $\mathrm{~N}$ & $\mathrm{~N}$ & $\mathrm{~N}$ & $P$ & $\mathrm{~N}$ & $\mathrm{~N}$ & $\mathrm{~N}$ & $P$ \\
\hline D-glucosamine & $\mathrm{N}$ & $\mathrm{N}$ & $\mathrm{N}$ & $\mathrm{N}$ & $P$ & $P$ & $P$ & $\mathrm{~N}$ & $\mathrm{~N}$ & $\mathrm{~N}$ & $P$ & $\mathrm{~N}$ & $\mathrm{~N}$ & $\mathrm{~N}$ & $\mathrm{~N}$ & $\mathrm{~N}$ & $\mathrm{~N}$ \\
\hline Cadavarine & $\mathrm{N}$ & $P$ & $\mathrm{~N}$ & $P$ & $P$ & $P$ & $P$ & $P$ & $P$ & $P$ & $\mathrm{~N}$ & $\mathrm{~N}$ & $P$ & $P$ & $P$ & $P$ & $\mathrm{~N}$ \\
\hline Ethylamine & $P$ & $\mathrm{~N}$ & $\mathrm{~N}$ & $P$ & $P$ & $P$ & $P$ & $P$ & $P$ & $P$ & $\mathrm{~N}$ & $P$ & $P$ & $P$ & $\mathrm{~N}$ & $P$ & $\mathrm{~N}$ \\
\hline Tryptophan & $\mathrm{N}$ & $\mathrm{N}$ & $\mathrm{N}$ & $\mathrm{N}$ & $\mathrm{N}$ & $P$ & $P$ & $\mathrm{~N}$ & $\mathrm{~N}$ & $P$ & $\mathrm{~N}$ & $\mathrm{~N}$ & $\mathrm{~N}$ & $\mathrm{~N}$ & $\mathrm{P}$ & $\mathrm{N}$ & $\mathrm{N}$ \\
\hline Lysine & $\mathrm{P}$ & $\mathrm{N}$ & $\mathrm{N}$ & $P$ & $P$ & $P$ & $P$ & $\mathrm{~N}$ & $P$ & $\mathrm{P}$ & $\mathrm{N}$ & $P$ & $P$ & $P$ & $\mathrm{~N}$ & $\mathrm{P}$ & $\mathrm{N}$ \\
\hline \multicolumn{18}{|c|}{ Growth temperature tolerance $\left({ }^{\circ} \mathrm{C}\right)$} \\
\hline 20 & $\mathrm{~N}$ & $P$ & $\mathrm{~N}$ & $\mathrm{~N}$ & $\mathrm{~N}$ & $\mathrm{~N}$ & $P$ & $\mathrm{~N}$ & $\mathrm{~N}$ & $\mathrm{~N}$ & $\mathrm{~N}$ & $\mathrm{~N}$ & $\mathrm{~N}$ & $\mathrm{~N}$ & $\mathrm{~N}$ & $\mathrm{~N}$ & $\mathrm{~N}$ \\
\hline 25 & $\mathrm{~N}$ & $\mathrm{P}$ & $\mathrm{P}$ & $P$ & $P$ & $\mathrm{P}$ & $\mathrm{P}$ & $P$ & $P$ & $\mathrm{~N}$ & $\mathrm{~N}$ & $P$ & $P$ & $P$ & $\mathrm{P}$ & $P$ & $P$ \\
\hline 30 & $P$ & $P$ & $P$ & $P$ & $P$ & $P$ & $P$ & $P$ & $P$ & $P$ & $P$ & $P$ & $P$ & $P$ & $P$ & $P$ & $P$ \\
\hline 35 & $P$ & $P$ & $\mathrm{~N}$ & $\mathrm{~N}$ & $P$ & $\mathrm{~N}$ & $P$ & $P$ & $P$ & $\mathrm{P}$ & $\mathrm{P}$ & $P$ & $P$ & $P$ & $P$ & $\mathrm{~N}$ & $P$ \\
\hline 37 & $\mathrm{P}$ & $P$ & $\mathrm{~N}$ & $\mathrm{~N}$ & $\mathrm{P}$ & $\mathrm{N}$ & $P$ & $P$ & $\mathrm{P}$ & $\mathrm{P}$ & $\mathrm{N}$ & $P$ & $\mathrm{~N}$ & $P$ & $\mathrm{~N}$ & $\mathrm{~N}$ & $\mathrm{~N}$ \\
\hline 40 & $\mathrm{~N}$ & $\mathrm{~N}$ & $\mathrm{~N}$ & $\mathrm{~N}$ & $P$ & $\mathrm{~N}$ & $\mathrm{~N}$ & $P$ & $\mathrm{~N}$ & $P$ & $\mathrm{~N}$ & $P$ & $\mathrm{~N}$ & $P$ & $\mathrm{~N}$ & $\mathrm{~N}$ & $\mathrm{~N}$ \\
\hline 45 & $\mathrm{~N}$ & $\mathrm{~N}$ & $\mathrm{~N}$ & $\mathrm{~N}$ & $\mathrm{~N}$ & $\mathrm{~N}$ & $\mathrm{~N}$ & $P$ & $\mathrm{~N}$ & $\mathrm{P}$ & $\mathrm{N}$ & $\mathrm{N}$ & $\mathrm{N}$ & $\mathrm{N}$ & $\mathrm{N}$ & $\mathrm{N}$ & $\mathrm{N}$ \\
\hline \multicolumn{18}{|l|}{ Other reactions } \\
\hline Cycloheximide & $P$ & $\mathrm{~N}$ & $P$ & $P$ & $\mathrm{~N}$ & $P$ & $\mathrm{~N}$ & $\mathrm{~N}$ & $\mathrm{~N}$ & $\mathrm{~N}$ & $\mathrm{~N}$ & $P$ & $\mathrm{~N}$ & $P$ & $\mathrm{~N}$ & $\mathrm{~N}$ & $P$ \\
\hline DBB & $\mathrm{N}$ & $P$ & $\mathrm{~N}$ & $\mathrm{~N}$ & $\mathrm{~N}$ & $\mathrm{~N}$ & $\mathrm{~N}$ & $\mathrm{~N}$ & $\mathrm{~N}$ & $\mathrm{~N}$ & $P$ & $\mathrm{~N}$ & $\mathrm{~N}$ & $\mathrm{~N}$ & $P$ & $P$ & $\mathrm{~N}$ \\
\hline 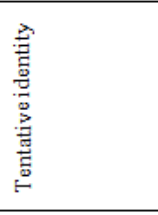 & 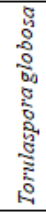 & 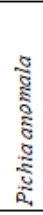 & 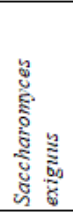 & 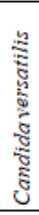 & 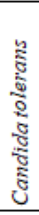 & 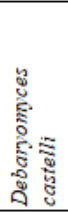 & 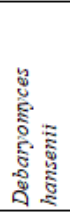 & 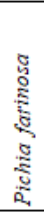 & 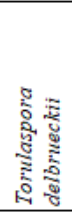 & 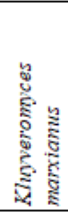 & 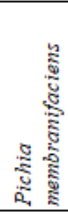 & 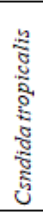 & 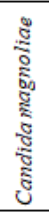 & 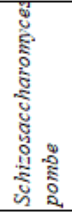 & 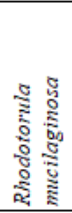 & 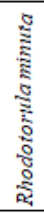 & 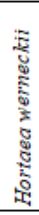 \\
\hline
\end{tabular}

1-DCHTM1; 2-DCHTM2; 3-DCHTM3; 4-DCHPG1; 5-DCHPG2; 6-IWHTP1; 7-MKHPM4; 8-MKHPG1; 9MKHPP2; 10-OSHTG2; 11-OSHTG3; 12-OSHTP1; 13-OSHPG1; 14-UPHTM1; 15-UPHTM2; 16-UPHTP1; $17-$ UPHPM2; TW-Tannish-white; Crm-Cream; Wte-White; Yell-Yellow; Bwn-Brown; -vex-Convex; -cave-Concave; Rsd-Raised; Buty-Butyrous; Sphe=Spherical; Med-Medium; Cylin-Cylindrical; P-hyphae-Pseudohyphae; PrPresent; A-Absent; P-Positive; N-Negative; D-Gal-D-Galactose; D-Ara-D-Arabinose; L-Rham-L-Rhamnose; DManni-D-Mannitol; D-Glucon-D-Gluconate; DBB-Diazonium blue-B

Debaryomyces: Yeast isolates IWHTP1 and MKHPM4 obtained from Iwo-okpom and Mkpanak creeks of the Qua Iboe Estuary respectively, were identified as species of the genus Debaryomyces. IWHTP1 was identified as Debaryomyces castelli strain IWHTP1 while isolate MKHPM4 was 
Statistical Distribution of Halotolerant/Halophilic Biosurfactant-Producing Yeasts in Qua Iboe Estuarine Sediments

identified as Debaryomyces hansenii strain MKHPM4. Whereas D. castelli was halotolerant growing in the presence of $8.75 \% \mathrm{NaCl}(\mathrm{w} / \mathrm{v}), D$. hansenii was halophilic, capable of growth in $17 \%$ $\mathrm{NaCl}$. Debaryomyces castelli could grow in $0.01 \%$ cycloheximide medium but $D$. hansenii could not. Range of temperature for growth of Debaryomyces hansenii was from $20^{\circ} \mathrm{C}$ to $37^{\circ} \mathrm{C}$ whereas $D$. castelli could only grow between the temperature range of 25 and $30{ }^{\circ} \mathrm{C}$. Neither of the two species could use nitrate sole source of nitrogen but $D$. hansenii could assimilate nitrogen from nitrite while $D$. castelli could not. On the contrary, Debaryomyces castelli could assimilate nitrogen from tryptophan whereas $D$. hansenii could not. Both strains were the most nutritionally versatile yeast strains in the study in terms of carbon assimilation. Debaryomyces hansenii could build up biomass and generate energy for sundy metabolic activities from all carbon sources screened in this study except inulin. Conversely, $D$. castelli failed to assimilate carbon from methanol, Dgluconate and D-arabinose. Their potentials for biosurfactant production were very similar especially in amount of surface-active compound produced, its effectiveness and efficiency. This is the first report on biosurfactant production potential of these two species of Debaryomyces under high salt conditions.

Rhodotorula: The characteristically red mucoid strain UPHTM2 was identified as Rhodotorula mucilaginosa while the pink butyrous colony was identified as Rhodotorula minuta. The redpigmenting mucoid Rhodotorula mucilaginosa strain UPHTM2 isolated from Upenekang sediments could assimilate nitrogen from nitrate and tryptophan while its pink counterpart could not. Contrariwise, $R$. minuta assimilated nitrogen from ethylamine while $R$. mucilaginosa could not. Neither of them could grow in the presence of $17 \% \mathrm{NaCl}$, so were described as halotolerant. Details of their differences and similarities in carbon assimilation is presented in Table 5. Not much difference was found in their biosurfactant production potentials with $R$. mucilaginosa releasing $165.34 \mathrm{~cm}^{2}$; the highest and most effective $(28.48 \mathrm{mN} / \mathrm{m})$ of all 17 yeasts biosurfactants studied. No detailed description of biosurfactant production by Rhodotorula minuta exists in literature, therefore this is the first report of such a potential and under high salt levels. Kawahara et al. [36] reported the production of a glycoprotein biosurfactant from Rhodotorula mucilaginosa isolated from the Antarctica and demonstrated its ability to stabilize astaxanthin. Sousa et al. [37] also reported biosurfactant production by a strain of Rhodotorula mucilaginosa using pineapple residues, however, the biosurfactant was not nearly as effective $(42.88 \mathrm{mN} / \mathrm{m})$ as that from the present study $(28.48$ $\mathrm{mN} / \mathrm{m}$ ), neither was it produced under high $\mathrm{NaCl}$ levels.

The remaining four yeast genera had a species each and included Saccharomyces exiguus strain DCHTM3, Kluyveromyces marxianus strain OSHTG2, Schizosaccharomyces pombe strain UPHTM1 and the black mucoid yeast Hortaea werneckii strain UPHPM2. Apart from Hortaea werneckii, the other three were halotolerant yeasts. Hortaea werneckii strain UPHPM2 was the most fastidious of all yeasts studied being only able to grow on glucose and lactose out of the 19 carbon sources screened for carbon assimilation. Its preferred nitrogen sources included nitrate and nitrite. The yeast could only grow at temperatures between 25 and $35^{\circ} \mathrm{C}$. The yeast accumulated biosurfactant that could cause an oil displaced area of $109.60 \mathrm{~cm}^{2}$. Interestingly, this biosurfactant was the most efficient with a critical micelle concentration $(\mathrm{cmc})$ of 18.71 $\mathrm{mg} / \mathrm{L}$. To the best of our knowledge, this is the first report on potential for biosurfactant production by a halotolerant strain of Hotaea werneckii, Saccharomyces exiguous, Schizosaccharomyces pombe. However, in this study, Kluyveromyces marxianus strain OSHTG2 produced a surface-active compound in the presence of $8.75 \% \mathrm{NaCl}(\mathrm{w} / \mathrm{v})$ which emulsified kerosene by $72.56 \%$ and was stable for more than 3 months at $4^{\circ} \mathrm{C}$. This result corroborates those by Lukondeh et al. [38] who reported the production of a natural mannan-protein emulsifying biosurfactant by Kluyveromyces marxianus strain FII 510700 when grown on lactosebased medium. Their bioemulsifier had an emulsification index of $70 \%$ when $\mathrm{NaCl}$ concentration was $5 \%$ as against the result of the strain in this study.

\section{Conclusion}

This study has identified a couple of novel yeast isolates with potentials to produce surface-active compounds under salt-stressed conditions. Excellent biosurfactant producer in the study included Rhodotorula mucilaginosa strain UPHTM2 that produced large amount of surface-active compound which was very effective and very efficient. Since all the biosurfactants produced by the 17 yeasts in this study could reduce surface tension to $<40 \mathrm{mN} / \mathrm{m}$, we conclude that halotolerant/halophilic yeasts in stressed environments secrete only effective surfaceactive compounds or not at all. Most of these biosurfactants when, exploited could find applications in microbial enhanced oil recovery and 
food processing where biosurfactant and/or bioemulsifier activity at high salt concentrations are desired.

\section{References}

1. Nanjwade, B.K., Chandrashekhara, S., Goudanavar, P.S., Shamarez, A.M. and Manvi, F.V. (2010) Production of antibiotics from soil-isolated actinomycetes and evaluation of their antimicrobial activities. Tropical Journal of $\begin{array}{llll}\text { Pharmaceutical } & \text { Research, } & \text { 9, 373-377 }\end{array}$ https://doi.org/10.4314/tjpr.v9i4.58933

2. Singh, R., Kumar, M., Mittal, A. and Mehta, P.K. (2017) Microbial metabolites in nutrition, healthcare and agriculture. 3 Biotech, 7, 15 https://doi.org/10.1007/s13205-016-0586-4

3. Moosavi-Nasab, M., Ansari, S. and Montazer, Z. (2007) Fermentative production of lysine by Corynebacterium glutamicum from different carbon sources. Iran Agricultural Research, 26, 99-106

4. Naraian, R. and Kumari, S. (2017). Microbial production of organic acids, In: Gupta, V.K., Treichel, H., Shapaval, V (O), Antonio de Oliveira, L. and Tuohy, M.G. (Eds.) Microbial functional foods and nutraceuticals. John Wiley and Sons Inc.

5. Fernandez-Cabezon, L., Galan, B. and Garcia, J.L. (2018) New insights on steroid biotechnology. Frontiers in $\begin{array}{llll}\text { Microbiology, } & \mathbf{8} & \text { Article } & 968\end{array}$ https://doi.org/10.3389/fmicb.2018.00958

6. Alia, K.B., Rasul, I., Azeem, F., Hussain, S., Siddique, M.H., Muzammil, S., Riaz, M., Amna Bari, A., Liaqat, S. and Nadeem, H. (2019) Microbial production of ethanol. Microbial Research Foundations, 46, 307-334.

7. Ritala, A., Häkkinen, S.T., Toivari, M. and Wiebe, M.G. (2017) Single cell protein-state-of-the-art, industrial landscape and patents 2001-2016. Frontiers in Microbiology, 8, Article 2009. https://doi.org/10.3389/fmicb.2017.02009

8. Josefsberg, J.O. and Buckland, B. (2012) Vaccine process technology. Biotechnology and Bioengineering, 109, 14431460 https://doi.org/10.1002/bit.24493

9. Chang, I., Jeon, M., and Gye-Chun Cho, G-C. (2015). Application of microbial biopolymers as an alternative construction binder for earth buildings in underdeveloped countries. International Journal of Polymer Science, 2015, $\begin{array}{llll}\text { Article ID } 326745, & 9 & \text { pages. }\end{array}$ https://doi.org/10.1155/2015/326745

10. Chattopadhyay, P., Banerjee, G. and Mukherjee, S. (2017) Recent trends of modern bacterial insecticides for pest control practice in integrated crop management system. 3 Biotech, 7 , https://doi.org/10.1007/s13205-017-0717-6

11. Ekpenyong, M., Asitok, A., Odey, A. and Antai, S. (2016) Production and activity kinetics of gelatinase by Serratia sp.SLO3. Nigerian Journal of Biopesticides, 1: 70-82

12. Edet, P.E., Asitok, A.D., Ekpenyong, M.G. and Antai, S.P. (2018) Evaluation of the effects of nutritional and environmental parameters on production of extracellular caseinolytic protease by Stenotrophomonas acidaminiphila strain BPE4. International Journal of Sciences, 7, 70-81 https://doi.org/10.18483/ijSci.1548

13. Ekpenyong, M.G., Antai, S.P., Asitok, A.D. and Ekpo, B.O. (2016) Plackett-Burman design and response surface optimization of medium trace nutrients for glycolipopeptide biosurfactant production. Iranian Biomedical Journal, 21, 249-260.

14. Accorsini, F.R., Mutton, M.J.R., Lemos, E.G.M. and Benincasa, M. (2012) Biosurfactants production using soybean oil and glycerol as low cost substrate. Brazillian
Journal of Microbiology, 2012, 116-125. https://doi.org/10.1590/S1517-83822012000100013

15. Bourdichon, F., Casaregola, S., Farrokh, C., Frisvad, J.C., Gerds, M.L., Hammes, W.P., Harnett, J., Huys, G., Laulund, S., Ouwehand, A., Powel, I.B., Prajapati, J.B., Seto, Y., Schure, E.T., Boven, A.V., Vankerckhoven, V., Zgoda, A., Tuijtelaars, S. and Hansen, E.B. (2012) Food fermentations: Microorganisms with technological beneficial use. International Journal of Food Microbiology, 154, 87-97 https://doi.org/10.1016/j.ijfoodmicro.2011.12.030

16. Kim, H., Yoo, S.J. and Kang, H.A. (2015) Yeast synthetic biology for the production of recombinant therapeutic proteins. FEMS Yeast Research, 15, 1-16 https://doi.org/10.1111/1567-1364.12195

17. Santos, D.K.F., Rufino, R.D., Luna, J.M. Valdemir A. Santos, V.A. and Sarubbo, L.A. (2016) Biosurfactants: multifunctional biomolecules of the $21 \mathrm{st}$ Century. International Journal of Molecular Sciences, 17, 401-431 https://doi.org/10.3390/ijms17030401

18. Mendes de Souza, P., Andrade Silva, N.R., Souza, D.G., Lima de Silva, T.A., Marta C. Freitas-Silva, M.C., Andrade, R.F.S., Silva, G.K.B., Albuquerque, C.D.C., Messias, A.S. and Campos-Takaki, G.M. (2018) Production of a biosurfactant by Cunninghamella echinulata using renewable substrates and its applications in enhanced oil spill recovery. $\begin{array}{llll}\text { Colloids and } & \text { Interfaces, } & \mathbf{2} & 63\end{array}$ https://doi.org/10.3390/colloids2040063

19. Varjani, S.J. and Upasani, V.N. (2017) Critical review on biosurfactant analysis, purification and characterization using rhamnolipid as a model biosurfactant. Bioresource Technology, 232, 389-397 https://doi.org/10.1016/j.biortech.2017.02.047

20. Udoh, T. and Vinogradov, J. (2019). Experimental investigations of behaviour of biosurfactants in brine solutions relevant to hydrocarbon reservoirs. Colloids and Interfaces, 3 https://doi.org/10.3390/colloids3010024

21. Essien, J.P., Benson, N.U., Antai, S.P. (2008) Seasonal dynamics of physicochemical properties and heavy metal burdens in mangrove sediments and surface water of the brackish Qua Iboe Estuary, Nigeria. Toxicological and Environmental Chemistry, 90, 259-273 https://doi.org/10.1080/02772240701550497

22. Itam, A.E., Digha, O.N., Effiong, M.P. and Ukot, A.A. (2016) Sources contribution to sediment along the Qua Iboe River/Estuary bank, South-East Nigeria. IOSR Journal of Applied Geology and Geophysics, 4, 1-6 https://doi.org/10.9790/0990-0405010106

23. Moses, E.A., Etuk, B.A. and Udosen, E.D. (2015) Spatial and seasonal variations in the contamination indices of trace metals in sediments from Qua Iboe River Estuary, SouthSouth, Nigeria. International Journal of science and Technology, 4 ,

$506-516$ https://doi.org/10.5455/jeos.20150714122504

24. Gunde-Cimerman, N. and Zalar, P. (2014) Extremely halotolerant and halophilic fungi inhabit brine in solar salterns around the globe. Food Technology and Biotechnology, 52, 170-179.

25. Ekpenyong, M.G., Antai, S.P. and Essien, J.P. (2007) Quantitative and qualitative assessment of hydrocarbon degrading bacteria and fungi in Qua Iboe Estuary, Nigeria. Research Journal of Microbiology, 2, 415-425 https://doi.org/10.3923/jm.2007.415.425

26. Ekpenyong, M.G., Antai, S.P. and Asitok, A.D. (2016) A Pseudomonas aeruginosa strain IKW1 produces an unusual polymeric surface-active compound in waste frying oilminimal medium. International Journal of Sciences, 5, 108123. https://doi.org/10.18483/ijSci.1064 
27. Ekpenyong, M., Antai, S., Asitok, A. and Ekpo, B. (2017) Response surface modeling and optimization of major medium variables for glycolipopeptide production. Biocatalysis and Agricultural Biotechnology, 10, 113-121 https://doi.org/10.1016/j.bcab.2017.02.015

28. Morikawa, M., Daido, H., Takao, T., Murata, S., Shimonishi, Y. and Imanaka, T. (1993) A new lipopeptide biosurfactant produced by Arthrobacter sp. Strain MIS38. Journal of Bacteriology, 175, 6459-6466. https://doi.org/10.1128/jb.175.20.6459-6466.1993

29. Rodrigues, L.R., Teixeira, J.A. and Oliveira, R. (2006) Lowcost fermentative medium for biosurfactant production by probiotic bacteria. Biochemical Engineering Journal, 32, 135142. https://doi.org/10.1016/j.bej.2006.09.012

30. Barnett, J.A., Payne, R.W. and Yarrow, D. (2000). Yeasts: Characteristics and identification. 3rd edition. Cambridge University Press, United Kingdom, Pp. 1139

31. Plemenitas, A., Lenassi, M., Konte, T., Kejzar, A., Zajc, J., Gostincar, C. and Gunde-Cimerman, N. (2014) Adaptation to high salt concentrations in halotolerant/halophilic fungi: a molecular perspective. Frontiers in Microbiology, 5, Article 199. https://doi.org/10.3389/fmicb.2014.00199

32. Zalar, P., Sybren de Hoog, G., Schroers, H-J., Frank, J.M. and Gunde-Cimerman, N. (2005) Toxonomy and Phylogeny of the xerophilic genus Wallemia (Wallemiomycetes and Wallemiales, cl. et ord. nov.). Antonnie von Leeuwenhoek, 82, 311-328. https://doi.org/10.1007/s10482-004-6783-x

33. Bodour, A.A., Drecs, K.P. and Maier, R.M. (2003). Distribution of biosurfactant-producing bacteria in undisturbed and contaminated arid southwestern soils. Applied and Environmental Microbiology, 69, 3280-3287 https://doi.org/10.1128/AEM.69.6.3280-3287.2003
34. Rubio-Ribeaux, D., Andrade, R.F.S., Sonia da Silva, G., Assuncao de Holanda, R., Pele, M.A., Nunes, P., Junior, J.C.V., Aparesida de Resende-Stoianoff, M. and CamposTakaki, G.M. (2017) Promising biosurfactant produced by a new Candida tropicalis UCP 1613 strain using substrates from renewable-resources. African Journal of Microbial Research, 11, 981-991 https://doi.org/10.5897/AJMR2017.8486

35. Thaniyavarn, J., Chianguthai, T., Sangvanich, P., Roongsawang, N., Washio, K., Morikawa, M. and Thaniyavarn, S. (2008) Production of sophorolipid biosurfactant by Pichia anomala. Biosciences, Biotechnology and Biochemistry, 2061-2068 https://doi.org/10.1271/bbb.80166

36. Kawahara, H., Hirai, A., Minabe, T. and Obata, H. (2013) Stabilization of astaxanthin by a novel biosurfactant produced by Rhodotorula mucilaginosa KUGPP-1. Biocontrol Science, $\quad 18, \quad 21-28$ https://doi.org/10.4265/bio.18.21

37. Sousa, T.G.C., Pinheiro, T.A., Camargo, H.A., Tambourgi, E.B., Sette, L.D., Cardoso, V.L., Coutinho-Filho, U. and Silveira, E. (2017) Production of biosurfactant from Rhodotorula mucilaginosa using pineapple residues. In: Proceedings of National bioprocess symposium and enzymatic hydrolysis of biomass symposium, 2017

38. Lukondeh, T., Ashbolt, N.J. and Rogers, P.L. (2003) Evaluation of Kluyveromyces marxianus FII 510700 grown on a lactose-based medium as a source of a natural bioemulsifier. Journal of Industrial Microbiology and Biotechnology, 30, 715-720 https://doi.org/10.1007/s10295003-0105-6 